\section{Aquaculture}

June 2006; 256(1-4) : 1-14

http://dx.doi.org/10.1016/j.aquaculture.2006.02.023

(c) 2006 Elsevier B.V. All rights reserved.
Archimer, archive institutionnelle de l'Ifremer http://www.ifremer.fr/docelec/

\title{
Bivalve genomics
}

\section{Carlos Saavedra $^{\mathrm{a}^{*}}$ and Evelyne Bachère ${ }^{\mathrm{b}}$}

\author{
${ }^{a}$ Instituto de Acuicultura de Torre la Sal, Consejo Superior de Investigaciones Científicas, 12595 Ribera de \\ Cabanes, Castellón, Spain \\ bUMR5871, IFREMER/CNRS/UM2, Université Montpellier 2, Place E. Bataillon, CC80, F-34095 Montpellier \\ Cedex 5, France \\ *: Corresponding author : Tel.: +34 964319 500; fax: +34 964319 509. saavedra@iats.csic.es
}

\begin{abstract}
Interest in bivalve genomics has emerged during the last decade, owing to the importance of these organisms in aquaculture and fisheries and to their role in marine environmental science. Knowledge of bivalve genome structure, function and evolution resulting from 20th century "single gene" approaches is limited, but genomic technologies are called to dramatically increase it. Research based on linkage maps, transcriptomics and proteomics is being carried out to study the genetic and molecular bases of traits of interest in bivalve farming industry, mainly disease susceptibility, tolerance to environmental stress, and growth. The Pacific oyster (Crassostrea gigas) is now the focus of an international genome-sequencing consortium. The use of bivalves in pollution monitoring has prompted the genomic study of the cell and organism responses to xenobiotics, which should expand into the field of phytoplankton toxins. Future work should also pay more attention to the larval stages, and to basic processes such as growth, sex-determination, and gonad development.
\end{abstract}

Keywords: Bivalves; Genomics; Proteomics; Stress; Feeding; Shellfish toxins 


\section{Introduction}

Bivalves constitute a source of food all over the world, with a production of over 13 million $\mathrm{Tm}$ in year 2002 (FAOSTAT data, last updated February 2004; http://apps.fao.org/default.jsp). Scientific bivalve aquaculture is now more than 50 years old (Loosanoff and Davis, 1963; Walne, 1974; Korringa, 1976, 1979), and has achieved a degree of technological development that includes regular production of polyploids (Nell, 2002) and ongoing selection and breeding programs (Sheridan, 1997; Nell et al., 1999; Calvo et al.,2003; Evans et al., 2003; Langdon et al., 2003; Nell and Hand, 2003; Zheng et al., 2004). Oysters, clams and scallops are among the 12 most important species in global aquaculture (Fig. 1). Bivalves also have an important role in the functioning of the ecosystems that they inhabit (Gosling, 2003), for example as a scaffold for rocky shore intertidal communities (mussels) or as extensive contributors to the transfer of mineral (e.g.: calcium) and organic matter in benthic habitats (oysters, scallops). Besides marine coastal habitats, bivalves are adapted to a variety of other environments, including freshwater, low-light deep sea, and turbid and oxygen-poor brackish waters, although the physiological and molecular bases of these adaptations are still poorly known. Due to filter feeding, bivalves can accumulate xenobiotic compounds, and, therefore, are organisms of choice for environmental monitoring, but also constitute potential risks for human health when they are eaten.

In response to the importance of bivalves in marine ecosystems and aquaculture, the study of bivalve genomics is beginning. Obviously, a genome sequence permits detailed knowledge of an organism's biology and is one of the most powerful tools in the hands of biologists today.. A proposal to sequence the genome of the Pacific oyster (Crassostrea gigas), has been put forward by the Oyster Genome Consortium (OGC), which is comprised of 70 individuals from 11 countries (Hedgecock et al., 2005). However, genomics is more than obtaining a complete genome sequence and has many other tools and aims, which share a focus on the simultaneous study of the whole genome, as opposed

to single-gene or multigene approaches typical of $20^{\text {th }}$ century molecular biology. This focus has been made possible by the development of highly sophisticated analytical tools (Gibson and Muse, 2005).

Here we review present knowledge of bivalve genomics, which has resulted primarily from classical single-gene studies, introduce the main areas of ongoing research with new genomic approaches, and describe the tools developed so far in these areas. We also identify specific topics of bivalve biology and aquaculture in which genomics has not been applied yet but could be particularly useful.

\section{The genome of bivalves}

The DNA content of the haploid bivalve genome ranges from $0.65 \mathrm{pg}$ to $5.4 \mathrm{pg}$ (Gregory, 2005). These values are in the middle of the range for the metazoans as a whole (Gregory, 2004). As can be seen in Fig. 2, bivalve genome sizes are comparable to those of model organisms whose genome has been already sequenced, or of other important cultured marine species. Haploid chromosome numbers for bivalves range from 10 to 23, and chromosomes tend to be very homogeneous in size (Thiriot-Quièvreux, 1994). This poses problems for identification under the microscope. Classical C- and G-banding provide no means to differentiate the chromosomes, but fluorescence in situ hybridization (FISH) with 
P1 clones have rendered good results in the American oyster Crassostrea virginica (Wang et al., 2005)

Our knowledge of the structure and gene content of bivalve genomes is less extensive than that for other major invertebrate groups and clearly less than that for vertebrates. We will summarize, first, the knowledge relative to the organization of the noncoding fraction. Repetitive DNA, either satellite or interspersed, is common in bivalves. Some satellite DNA families have been characterized in the clam Donax trunculus (Plohl and Cornudella, 1996; Petrovic and Plohl, 2005), mussels (Martínez Lage et al., 2002, 2005), oysters (Clabby et al., 1996; López-Flores et al., 2004) and the Antarctic scallop Adamusium colbeckii (Canapa et al., 2000). One single satellite DNA has been estimated to comprise $0.63 \%$ of the genome of the blue mussel Mytilus edulis, and another accounts for $1-4 \%$ of the Pacific oyster genome, suggesting that the repetitive DNA fractions of bivalve genomes are quite large, in agreement with early studies based on reassociation kinetics (Clabby et al., 1996; Goldberg et al., 1975; Ruiz-Lara et al., 1999). Martínez-Lage et al. (2005) studied three satellite DNAs in four Mytilus species and 10 additional bivalves. They found that abundant satellite motifs in one species can be present in lower copynumber in even closely related species, and suggested that these differences across species support the "library hypothesis" of Nijman and Lenstra (2001). This hypothesis proposes that there is a set of conserved satellite DNA sequences in a group of organisms, and different sequences spread randomly in the genome of different species. The location of the some satellite DNAs (centromeric, telomeric, interspersed) has been studied by Southern blotting or FISH (Martínez-Lage et al., 2002; Plohl and Cornudella, 1997; Plohl et al., 2002; Wang et al., 2001). FISH mapping has revealed that bivalves are the only invertebrates that carry the vertebrate telomeric sequence (Guo and Allen, 1997; GonzálezTizón et al., 1998; Wang and Guo, 2001). Transposable elements have been found in bivalves (Arkhipova and Meselson, 2000), and some repetitive DNAs seem to be related to transposons (Gaffney et al., 2003; López-Flores et al., 2004).

\section{Our present knowledge of nuclear genes in bivalves}

A search of the GenBank database for the keywords "Mollusca" + "Bivalvia" returned over 32000 entries, which is not much when compared to other completely aquatic zoological groups such as fishes (more than 2 million entries), or annelid worms ( 19000 entries). Bivalve mitochondrial sequences are exceedingly abundant in databases, if we consider that they represent only a very small fraction of the total DNA and gene content (Fig. 3a). This is attributable to their special intrinsic interest (see below) and the use of mtDNA as a tool of choice in population genetics and phylogenetics.

By species, DNA databases are dominated by oysters (Crassostrea sp), bay scallops (Argopecten irradians) and mussels (Mytilus sp), with Pecten scallops following far away (Fig. 3b). It is remarkable that of the three bivalve species that appear among the "top 12" aquacultured organisms at a global scale (Fig. 1), two of them, the Japanese or Yesso scallop (Patinopecten yessoensis) and the Manila clam (Ruditapes philippinarum), are minimally represented in GenBank (less than 1\% each) (Fig. 3b).

A large fraction of the nuclear sequences in GenBank is the result of 20th century "single-gene" research (as opposed to $21^{\text {st }}$ century whole-genome approaches). The nature of these sequences reflects the interests of the scientific community as well as several characteristics of the bivalves themselves, and can be classified in the following categories: 
- Exclusive characteristics of bivalves have been studied from a genetic perspective. The genes coding for proteins of the byssus, a bunch of threads by which some bivalves attach to the substrate during part or the whole adult life, have been cloned and studied (Inoue et al., 1996; Coyne et al., 1997; Anderson and Waite, 1998; Waite and Quin, 2001). Genes involved in the formation of the shell have also been reported (Sarashina and Endo, 2001; Zhang et al., 2003; Li et al., 2004). In both cases, a stimulus for research has been its potential industrial utility in the field of natural cements (byssus proteins) and the pearl industry (shell formation).

- Some information has been collected on genes related to immunity and disease resistance, especially in mussels and oysters, which includes sequences of genes coding for several anti-microbial peptides and pathogen defense-related proteins (Mitta et al., 2000; Nilsen and Myrnes, 2001; Montagnani et al., 2001). This information is of obvious applied interest in aquaculture.

- Bivalves, especially mussels, have been extensively used for monitoring environmental changes and the effect of these changes on the performance of marine organisms. Several laboratories have cloned genes related to pollution and stress response in bivalves (Barsyte et al., 1999; Butler et al., 2001; Tanguy et al., 2003; Jenny et al., 2004; Tagaki et al., 2004; Yang et al., 2004; Boutet et al., 2004, 2005).

- Basic metabolic processes, such as respiration (Piro et al., 1998; Jia et al., 1999; Kimura et al., 2005), energy storage (Suzuki and Yamamoto, 2000; Suzuki et al., 2002; Takeuchi et al., 2004), calcium metabolism (Dubos et al., 2003), digestion (Xu et al., 2001, 2002; Sellos et al., 2003; Kothemyako et al., 2004), development (Barucca et al., 2003; Canapa et al., 2005; Pérez-Parallé et al., 2005), muscle contraction (Iwasaki et al., 1997; Yamada et al., 1999; Watabe et al., 2000; Funabara et al., 2001a, b), protein turnover (Donald et al., 2001), neuronal activity (Cadet and Stefano, 1999) or reproduction (Matsumoto et al., 2003) have been studied in bivalves from a molecular biology perspective, which resulted in cloning genes coding for several proteins involved in those processes. Genes coding for some proteins of structural function have also been cloned (Carlos et al., 1993; Ruiz-Lara et al., 1993).

- Finally, many database entries refer to ribosomal genes and spacers, which have been used mainly in phylogenetics and population genetics research. Still, our present knowledge of the systematics and phylogeny of bivalves is poor and malacologists have not agreed on the relationships of many of the basal categories within the class (Steiner and Müller, 1996; Giribet and Carranza, 1999; Giribet and Wheeler, 2002).

In summary, research on several processes of general biological interest (evolution, development), as well as of applied interest in biotechnology and aquaculture (digestion, immunity, stress resistance, byssus and shell formation), have been attacked from a classical molecular biology perspective in the last two decades. They have produced only a small collection of information pieces about the bivalve genome and its functional role. At present, the knowledge of the molecular and cellular mechanisms involved in the main physiological processes of interest in aquaculture (growth, reproduction, immunity) is very small. Genomic approaches are needed to increase dramatically our knowledge of those processes.

Mitochondrial genomes 
The mitochondrial component of the genome is especially interesting in bivalves because some species show a particular type of inheritance called "doubly uniparental" (DUI) (reviewed in Zouros, 2001). Species with DUI have two types of mitochondrial genomes, called $\mathrm{F}$ and $\mathrm{M}$, which are transmitted through females and males, respectively, with males being heteroplasmic and females homoplasmic for F (Skibinski et al., 1994; Zouros et al., 1994). Complete or nearly complete sequences of mitochondrial genomes are already available for 6 species in public databases, including the $\mathrm{F}$ and $\mathrm{M}$ genomes of the Mediterranean mussel Mytilus galloprovincialis, the Manila clam Ruditapes philippinarum and the freshwater mussel Inversidens japanensis, and the F genomes of the blue mussel $M$. edulis, the freshwater mussel Lampsilis ornata, and the Pacific oyster Crassostrea gigas, in which DUI has not been reported (Mizi et al., 2005, and references therein). It has been shown that $\mathrm{F}$ and $\mathrm{M}$ genomes can recombine in species with DUI (Ladoukakis and Zouros, 2001; Rokas et al., 2003). Also, DUI has been related to extreme biases in family sex ratio, which have a nuclear genetic basis (Zouros et al., 1994; Saavedra et al., 1997; Kenchington et al., 2003). Functional differences between $\mathrm{F}$ and $\mathrm{M}$ genomes are now beginning to be studied (Dalziel and Stewart, 2002). Mapping approaches to identify the genomic locations of the genes responsible for sex-determination, sex-ratio bias and alternative patterns of $\mathrm{M}$ genome transmission could shed light on the mechanistic basis of these phenomena, while functional genomics offers powerful tools to understand their molecular bases.

\section{Genomic tools in bivalves}

\section{Genomic libraries}

Many types of libraries have been developed to facilitate the handling and storage of the large amounts of DNA contained in cells. The use of expression libraries packaged in viral or plasmid vectors is commonplace in modern laboratories. However, the more recent development of vectors for constructing libraries of large pieces of DNA (in the order of millions of base pairs) has facilitated genomic analysis. These vectors include fosmid, bacterial artificial chromosomes (BAC) and P1-derived artificial chromosomes (PAC) (Kimet al., 1992; Shizuya et al., 1992; Ioannou et al., 1994). BAC libraries have become one of the favorite tools for collection and archival of genomic material, also in non-model organisms (e.g.: Thorsen et al., 2005). They are often the first step towards the sequencing of an organism's genome (Gibson and Muse, 2002). They are also used for the construction of physical maps (e.g.: Ng et al., 2005). Among bivalves, only the commercial oysters have been the subjects of BAC library construction (see details in Hedgecock et al., 2005). Since BAC libraries facilitate enormously the handling of long genomic fragments, its use should rapidly expand to other intensively exploited commercial bivalves.

\section{EST collections}

Expressed sequence tags (EST) are sequences of genome fragments obtained from a library of cDNAs by sequencing the ends of the inserts. The generation of EST collections has been a popular tool for initiating genomic research in model (e.g.: sea urchin; Poustka et al., 2003) and non-model organisms (e.g.: salmon; Rise et al., 2004), because it produces information on the part of the genome that is actually expressed, and can be used afterwards in various ways (e.g.: gene fishing, microarrays). Several EST collections have already 
been reported in commercial bivalves, and they account for the large numbers of sequences available in public databases for oysters, mussels, and scallops as compared to other bivalve species (Fig. 3b). Until March 2005, 14 EST collections from bivalves had been published or made available in public databases (Table 1). With only one exception (the invasive zebra mussel Dreissena polymorpha), all were focused on farmed species. These collections have provided a substantial number of sequences that are similar to genes already isolated in other organisms, but they are characterized by a large proportion ( $50 \%)$ of no hit sequences, which show no similarity to known genes after BLAST search against databases (Fig. 4). A high potential for the discovery of new genes and, perhaps, new metabolic routes and gene networks is suggested by these data. Consortia of several laboratories have emerged in order to produce and manage these kinds of data, such as the Marine Genomics project in America (www.marinegenomics.org) (McKillen et al., 2005), or the Marine Genomics Europe Network of Excellence (MGE) (www.marine-genomicseurope.org). One of the main objectives of these initiatives is the production, in the next few years, of large amounts of ESTs from many marine species, including cultivated bivalves such as the bay scallop, the Pacific and American oysters, blue mussels (Mytilus sp.), and clams (Ruditapes sp.).

\section{Microarrays}

Much of the current cDNA sequencing effort is directed towards the construction of microarrays (Schena et al., 1995), which are extremely useful tools to study different physiological functions (Stoughton, 2005; von Schalburg et al., 2005). An international collaboration has been initiated among laboratories in North America and France to produce a multi-species microarray containing over 6,000 cDNAs from C. virginica, $C$. gigas and the oyster pathogen Perkinsus marinus (see Hedgecock et al., 2005). Within the framework of the MGE Network, a specific C. gigas microarray will be constructed using representative ESTs of different tissues (hemocytes, gills, gonads, mantle and digestive gland). The MGE Network will also produce microarrays containing mussel (Mytilus) and clam (Ruditapes) genes. .

\section{DNA polymorphisms}

An important fraction of the nuclear genome entries in GenBank comprises microsatellite-containing genome fragments (Fig. 3a). Microsatellites are the most popular molecular markers in quantitative genomics (Goldstein and Schlötterer, 1999). Most bivalve microsatellite sequences deposited in databases come from the Pacific oyster $C$. gigas, which is the subject of ongoing breeding programs. Abundance of microsatellites seem to vary widely even among closely related species of bivalves, and dinucleotide microsatellites are far more abundant than any other type of microsatellites, as has been observed in most other metazoans (Cruz et al., 2005).

Screenings of single nucleotide polymorphisms (SNP) in bivalves are beginning and first results indicate a high frequency of single nucleotide polymorphisms (1 per $40 \mathrm{bp}$ ) and insertion/deletion (1 per $33 \mathrm{bp}$ ) polymorphisms in oyster ESTs (Curole and Hedgecock 2005). Low throughput technologies, such as single strand conformation polymorphisms (SSCP) (Orita et al., 1989) or denaturing gradient gel electrophoresis (DGGE) (Miller et al., 1999), allow scoring for multiple single-base polymorphisms at ESTs or other genome 
fragments (Ortí et al., 1997). These technologies will tend to be substituted by high throughput technologies already available for nucleotide genotyping (Kwok 2001). Pyrosequencing (Milbury et al., 2004), quantitative PCR-based 5'-nuclease and allelespecific PCR (Elfstrom et al., 2005), and mass spectrometry (D. Jolivet, Station Biologique de Roscoff, pers. comm.) have been used thus far. In the near future, these and other methodologies will allow full automation of the genotyping process in natural populations and pedigreed farmed stocks of bivalves.

\section{Linkage maps and quantitative genomics}

A linkage map of the Pacific oyster's genome, based on more than 100 microsatellites, has been published recently (Hubert and Hedgecock, 2004), and AFLPbased maps of the American and Pacific oysters, and Zhikong scallops, have also been produced ( $\mathrm{Li}$ and Guo, 2004; Yu and Guo, 2003; Wang et al., 2005). These studies have shown that recombination rates are very different between sexes in oysters (as they are in other organisms). Hubert \& Hedgecock (2004) also found inter-individual variation in recombination rates and gene order, possibly indicative of polymorphisms for chromosomal rearrangements. Mapping efforts have been initiated in other species such as the blue mussel (P. Boudry, IFREMER- La Tremblade, pers. comm.; P. Presa, University of Vigo, pers. comm.) and the Manila clam (C. Saavedra, unpublished results).

Linkage maps are usually carried out in the framework of quantitative genomics programs, i.e., mid to long term studies directed to locate genomic regions underlying phenotypic variation for a given trait, usually of economic importance (Liu, 1997). The interdisciplinary team nucleated by IFREMER (the French Institute for Research and Exploitation of the Sea) is producing large amounts of markers as well as experimental populations for carrying out quantitative trait loci (QTL) studies in the Pacific oyster. In particular, facing the phenomenon of summer mortalities occurring regularly in French oyster culture beds, a program has been launched to select families for low and high survival rates. At present, a second generation, multifamily pedigree is available for QTL mapping (MOREST program: http://www.ifremer.fr/morest). Oyster QTL mapping efforts are also taking place in Australia (McGoldrick et al., 2002) and the United States (Hedgecock et al. 2004).

One of the problems faced by linkage mapping and QTL studies in bivalves is that genotype proportions in the offspring of crosses deviate moderately to largely from those expected under Mendelian segregation, on which the performance of mapping algorithms is based (McGoldrick and Hedgecock, 1997; Bierne et al., 1998; Launey and Hedgecock 2001). Hubert and Hedgecock (2004) overcame this difficulty by using larvae for genotyping the mapping population, because previous studies had shown that deviations from Mendelian ratios appeared at the end of the larval period or later. Yet, traits of interest for QTL mapping are usually expressed in adult animals. On the other hand, maps have been successfully constructed in species exhibiting moderate amounts of segregation distortion (Schwartz-Sommeer et al., 2003). Clearly, more theoretical work is needed to clarify the effects of transmission distortion on linkage and QTL detection, and to develop new algorithms that take into account this potential cause of bias.

\section{Functional genomics of traits of interest in bivalve aquaculture}


Transcriptomic approaches to stress tolerance, pathogen resistance and hybrid vigor

The genomic analysis of traits that are of special importance from the viewpoint of bivalve farming has begun in recent years, mainly through the study of gene transcription patterns. cDNA libraries, EST collections and the subsequent printing of microarrays are being used as a general approach to identify genes with putative functions in the cellular and biochemical processes underlying these traits. So far, these studies have been limited to the Pacific oyster, and have been reviewed recently (Hedgecock et al., 2005). Here we will provide only a succinct account to illustrate the use of tools described in the previous section. Immunity and pathogen resistance are the traits that have received special attention. The expression of resistance or sensitivity to diseases is often linked to environmental stress, which can be produced by changes in temperature and salinity, or anoxia (Burreson and Calvo 1996). Jenny et al. (2002) produced two EST collections from embryos and hemocytes of the American oyster $C$. virginica to identify genes potentially related to stress response. They identified 29 transcripts, which could be potential biomarkers, including recognition proteins, proteins of the acute-phase response, proteinases, proteinase inhibitors, other potential immune effectors, and other related biomarkers. Gueguen et al. (2003,) produced a cDNA library from hemocytes of bacteria-challenged Pacific oysters. Putative functions were assigned to $54 \%$ of 1142 sequenced cDNAs and all EST information is available through search profiles on a public database (http://www.ifremer.fr/GigasBase/).

More specific studies have been carried out by means of libraries produced by suppression subtractive hybridization (SSH) (Diatchenko et al., 1999). EST sequences were obtained from a SSH between mantle and gonad RNAs from Pacific oyster progenies selected for resistance and sensitivity to summer mortality phenomenon (Huvet et al., 2004). Some genes were identified as candidates for further investigation. Tanguy et al. (2004) employed this approach to find genes related to the differential response of American and Pacific oysters to the parasite Perkinsus marinus. The two oyster species show very different degrees of sensitivity. When they compared infected and control strains in both species, they found 107 genes which were differentially expressed in $C$. virginica, and 69 in C. gigas. The study uncovered differences in gene expression between the two oyster species, which provided candidate genes for further study. Stress tolerance and pathogen resistance in oysters are now being approached through microarrays, through an international collaboration among several North American and French laboratories (Hedgecock et al., 2005).

Hybrid vigor or heterosis, the phenomenon by which hybrid strains grow faster or survive better than parental strains, is a common observation in farmed animals and the basis of many commercial strains of animals and plants. Heterosis at the molecular level in bivalves was discovered 25 years ago as a relationship of growth and survival with protein heterozygosity as scored by gel electrophoresis. Since then, it has been one of the major topics of genetic research in bivalves (Pogson and Zouros, 1994; Hedegecock et al., 1996; Bierne et al., 1998; Launey and Hedgecock, 2001). The extremely powerful technique of massively parallel signature sequencing has been used by D. Hedgecock's team (University of Southern California, USA), in collaboration with a private biotechnology company to study the molecular basis of heterosis in the Pacific oyster by screening the whole transcriptome (Hedgecock et al., 2005, and references therein). 
Proteomic approaches to stress tolerance

Proteomics has been applied to the study of stress factors on the quality of commercial blue mussels (Mytilus sp). López et al. (2001, 2002b) performed twodimensional electrophoresis on 16 individuals of Mytilus galloprovincialis and M. edulis and distinguished 1278 spots per gel, of which 420 were subjected to further analysis. Significant differences in expression between the two species, as indicated by differences in staining intensity, were observed at 37 proteins. By using Matrix-assisted laser desorption ionization/time-of-flight (MALDI-TOF) and nanoelectrospray ion trap (NESI-ITB), 15 peptides could be identified, including seven which exhibited some of the highest expression differences between species. Interestingly, higher expression levels were found at two stress-related proteins (HSP-70 and calreticulin) in animals coming from an intertidal population, which experienced a highly variable environment, than in animals from a cultivated population, with a more stable environment. Subsequent study of mussel crosses showed that hybrid mussels had altered expression patterns for several polypeptides, including underexpression of HSP-70 and calreticulin, as compared to homospecific crosses of $M$. galloprovincialis (Fuentes et al., 2002). In a further comparison of the two cited species with M. trossulus from the Baltic Sea of much lower salinity, it was found that one polypeptide out of 6 showed one amino acid difference in $M$. trossulus after MALDI-TOF peptide mapping (López et al., 2002 a). The protein showing the difference was identified as tropomyosin.

These studies show the utility of proteomic approaches for the genetic characterization of species such as bivalves, which have not been well characterized previously at the genomic or proteomic level, and to advance in the knowledge of diverse aspects of their biology.

\section{Environmental genomics}

\section{Pollution and shellfish toxins}

Biotoxins and pollutants are environmental factors of special concern in bivalve aquaculture, because they can induce stress and reduce production yield and quality, provoke mortalities, and affect human health. Bivalves are organisms of choice to study the effect of marine pollution on physiology. Several genomic approaches, such as the production of cDNA libraries, microarrays and proteomics are being used to study the effect of pollutants on key bivalve species (e.g.: Knigge et al., 2004; Rodríguez-Ortega et al., 2003; Tanguy et al., 2005; Venier et al., 2003). Of more immediate importance is the widespread phenomenon of accumulation of phytoplankton toxins in bivalves (Bricelj and Shumway, 1998; Burgess and Shaw, 2001). Some toxins affect the animals, while others do not affect the animals, but affect humans who eat them (Brett, 2003), which can result in important economical losses for shellfish farmers and fishermen due to bans on shellfish extraction. While some bivalve species readily detoxify, it takes up to several weeks for other species (e.g., scallops) to eliminate the toxins (Shumway and Cembella, 1993). The network of molecular processes involved in detoxification and cell responses to toxins is far from being well understood (Bricelj and Shumway, 1998; Burgess and Shaw, 2001). A recent study showed a molecular basis for differences in sensitivity to paralytic shellfish 
toxin (PST) in the clam Mya arenaria (Bricelj et al., 2005). Populations with a different history of exposure to toxic algae blooms showed adaptation to PST due to a single nucleotide mutation, which caused an amino acid replacement in the $\mathrm{Na}^{+}$channel outer pore, the binding site for PST. This mutation increased clam survival after exposure to the toxic microalgae responsible for PST production. While this work shows the molecular basis of clam resistance to toxins, the basis for differences in depuration rate among bivalve species remains unknown. Due to its expected complexity, study of detoxification in bivalves will clearly benefit from genomic and transcriptomic approaches (Rossini, 2005).

\section{Feeding and nutrition}

Several aspects of the feeding and nutrition physiology have been studied in bivalves, especially ingestion and clearance rates, and enzymatic activities and their variation across tissues or ecological conditions (e.g.: Reid, 1968; Bayne et al., 1987; Ibarrola et al., 1996; Labarta et al., 2002). However, detailed molecular characterization of these processes is lacking, although some genes coding for digestive enzymes have been cloned and described (Xu et al., 2001, 2002; Sellos et al., 2003; Kothemyako et al., 2004). Genomic technologies provide extremely powerful tools to deal with these issues. cDNA libraries from different parts of the digestive tract and subsequent microarray and quantitative PCR studies can reveal patterns of expression of the set of genes involved in digestion and absorption, and their response to environmental parameters.

A fundamental aspect of bivalve culture is the design of diets of quality that guarantee optimal larval survival, spat growth or sexual maturation (Walne, 1974; Knauer and Southgate, 1999). One of the handicaps of diet design is the poor knowledge of diet composition of cultivated species in their natural environment. A promising approach to this issue will be the use of "environmental genomics" (Venter et al., 2004) in the context of gut content analysis. This methodology, which has been very successful in the area of microbial marine biodiversity, consists in the isolation of microorganisms by filtering, subsequent extraction of bulk DNA from the sample, and PCR amplification of one or more target genes with universal primers that work in a wide array of taxa. After cloning and sequencing a large amount of target fragments, the identification of the species that are present in the sample can be carried out by comparing the sequences with those available in databases (e.g.: Moon van der Staay et al., 2001). This methodology has allowed Duplessis et al. (2004) and Blakenship and Yayanos (2005) to characterize the gut contents in the bivalve Lucinoma aequizonata and other marine invertebrates. In a further step, the use of arrays containing a large number of sequences from microorganisms potentially constituting part of bivalve food could be used to study the composition of diets of animals growing in different localities, and help localize the best places for farming. Ecological genomic approaches to bivalve feeding will also enhance the understanding of food webs in marine ecosystems.

\section{Larval genomics}

An important aspect of the research summarized to this point is that is has been focused on adult animals. However, bivalves display at least three well-recognized larval stages (trochophore, veliger and paediveliger)(Gosling, 2003), and the knowledge of the molecular and cell biology of these stages is almost inexistent. An immediate question is 
whether different blocks of genes are expressed at these different stages and in adults, and for what physiological functions. Larvae suffer pollution and stress at least as much as adults, and larval mortality is a source of concern in farms. Basic molecular techniques are applicable to bivalve larvae (Steele et al., 1999; Bierne et al, 1999), and a collection of ESTs from scallop larvae has already been deposited in public databases (Table 1). Proteomic methods have been applied also to the study of bivalve larvae (López et al., 2005). Future genomic studies should pay more attention to this important stage of the bivalve life cycle.

\section{Concluding remarks}

Genomics and proteomics offer powerful tools for attacking complex problems of fundamental importance for progress in bivalve aquaculture industry. However, these tools need accompanying progress in other aspects. First, the development of populations designed specifically to address particular topics is necessary: selected strains, wellcharacterized local races, and mutant phenotypes. Some are already available in the Pacific oyster (reviewed in Hedgecock et al., 2005). On the other hand, cell biology tools, such as cell lines, are not yet available in bivalves. This goal will surely benefit from genomic and proteomic tools (Rinkevich, 2005). Finally, our knowledge of the very basic physiological processes, such as the regulation of growth or sexual maturation, is extremely poor at the molecular level in bivalves. Genomics offers extremely powerful tools to increase this knowledge, which would certainly increase the chances of improving bivalve aquaculture.

\section{Acknowledgements}

This work has been funded by the European Commission through the Network of Excellence "Marine Genomics Europe” (GOCE-CT-505403). We thank the Network's Fish \& Shellfish Node members for their fruitful discussions, and especially Drs. E. Zouros and A.Canario for their encouragement. We also would like to acknowledge two anonymous referees for their valuable suggestions. C.S. wishes to acknowledge additional funding from the Ministerio de Educación y Ciencia (Spain) through the "Ramón y Cajal” Program and research grant ACU-03-0028. 


\section{References}

Anderson, K. E., Waite, J.H., 1998. A major protein precursor of zebra mussel (Dreissena polymorpha) byssus: deduced sequence and significance. Biol. Bull. 194, 150-160.

Arkhipova, I., Meselson, M., 2000. Transposable elements in sexual and ancient taxa. Proc. Natl. Acad. Sci. USA, 97, 14473-14477.

Barsyte, D., White, K.N., Lovejoy, D.A., 1999. Cloning and characterization of metallothionein cDNAs in the mussel Mytilus edulis L. digestive gland. Comp. Biochem. Physiol. C 122, 287-296.

Barucca, M., Olmo, E., Canapa, A., 2003. Hox and paraHox genes in bivalve molluscs. Gene 317, 97-102.

Bierne, N., Launey, S, Naciri-Graven, Y., Bonhomme, F., 1998. Early effect of inbreeding as revealed by microsatellite analyses on Ostrea edulis larvae. Genetics 148, 18931906.

Blankenship, L.E., Yayanos, A.A., 2005. Universal primers and PCR of gut contents to study marine invertebrate diets. Mol. Ecol. 14, 891-899.

Boutet, I., Meisterzheim, A.-L., Tanguy, A., Thébault, M.-T., Moraga, D., 2005. Molecular characterization and expression of the gene encoding aspartate aminotransferase from the Pacific oyster Crassostrea gigas exposed to environmental stressors. Comp. Biochem. Physiol. C 140, 69-78.

Boutet, I., Tanguy, A., Moraga, D., 2004. Characterisation and expression of four mRNA sequences encoding glutathione S-transferases pi, mu, omega and sigma classes in the Pacific oyster Crassostrea gigas exposed to hydrocarbons and pesticides. Mar. Biol. 146, 53-64.

Brake, J., Davidson, J., Davis, J., 2004. Field observations on growth, gametogenesis, and sex ratio of triploid and diploid Mytilus edulis. Aquaculture 236,179-191 .

Brenner, S., Johnson, M., Bridgham, J., Golda, G., Lloyd, D.H., Johnson, D., Luo, S., McCurdy, S., Foy, M., Ewan, M., Roth, R., George, D., Eletr, S., Albrecht, G., Vermaas, E., Williams, S.R., Moon, K., Burcham, T., Pallas, M., DuBridge, R.B., Kirchner, J., Fearon, K., Mao, J., Corcoran, K., 2000 a. Gene expression analysis by massively parallel signature sequencing (MPSS) on microbead arrays. Nat. Biotechnol. 18, 630-634.

Brenner, S., Williams, S.R., Vermaas, E. H., Storck, T., Moon, K., McCollum, C., Mao, J., Luo, S., Kirchner, J. J., Eletr, S., DuBridge, R. B., Burcham, T., Albrecht, G., 2000 b. In vitro cloning of complex mixtures of DNA on microbeads: physical separation of differentially expressed cDNAs. Proc. Natl. Acad. Sci. USA 97, 1665-1670.

Brett, M.M., 2003. Food poisoning associated with biotoxins in fish and shellfish. Curr. Opin. Infect. Dis. 16, 461-465.

Bricelj, V.M., Connell, L., Konoki, K., MacQuarrie S.P., Scheuer,T., Catterall, W.A., Trainer,V.L., 2005. Sodium channel mutation leading to saxitoxin resistance in clams increase risk of PSP. Nature 434, 763-767.

Bricelj, V.M., Shumway, S.E., 1998. Paralytic shellfish toxins in bivalve molluscs: occurrence, transfer kinetics and biotransformation. Rev. Fish. Sci. 6, 315-383.

Burgess, V., Shaw, G., 2001. Pectenetoxins-an issue for public health: a review of their compartive toxicology and metabolism. Environ. Int. 271, 275-283.

Burreson, E.M., Calvo, L., 1996. Epizootiology of Perkinsus marinus disease of oysters in Chesapeake Bay, with emphasis on data since 1985. J. Shellfish Res. 15, 17-34. 
Butler, R.A., Kelley, M.L., Powell, W.H., Hahn, M.E., van Beneden, R.J., 2001. An aryl hydrocarbon receptor (AHR) homologue from the soft-shell clam, Mya arenaria: evidence that invertebrate AHR homologues lack 2,3,7,8-tetrachlorodibenzo-p-dioxin and $\beta$-naphtoflavone binding. Gene 278, 223-234.

Cadet, P., Stefano, G.B., 1999. Mytilus edulis pedal ganglia express mu opiate receptor transcripts exhibiting high sequence identity with human neuronal mu1. Mol. Brain Res. 74: 242-246.

Calvo, L.M.R., Calvo, G.W., Burreson, E.M., 2003. Dual resistance in a slectively bred eastern oyster, Crassostrea virginica, strain tested in Chesapeake Bay. Aquaculture 220, 69-87.

Canapa, A., Barucca, N., Cerioni, P.N., Olmo, E., 2000. A satellite containing CENP-B box-like motifs is present in the Antarctic scallop Adamussium colbecki. Gene 247, 175-180.

Canapa, A., Biscotti, M.A., Olmo, E., Barucca, M., 2005. Isolation of Hox and ParaHOx genes in the bivalve Pecten maximus. Gene 348, 83-88.

Carlos, S., Utalrs, L., Borrell, I., Hunt, D.F., Ausio, J., 1993. Sequence and characterization of a sperm-specific histone H1-like protein of Mytilus californianus. J. Biol. Chem. 268, 185-194.

Clabby, C., Goswami, U., Flavin, F., Wilkins, N.P., Houghton, J.A., Powell, R., 1996. Cloning, characterization and chromosomal location of a satellite DNA from the Pacific oyster, Crassostrea gigas. Gene 168, 205-209.

Coyne, K.J., Quin, X.X., Waite, J.H., 1997. Extensible collagen in mussel byssus: a natural block copolymer. Science 277, 1830-1832.

Cruz, F., Pérez, M., Presa, P., 2005. Distribution and abundance of microsatellites in the genome of bivalves. Gene 346, 241-247.

Curole, J.P., Hedgecock, D., 2005. High frequency of SNPs in the Pacific oyster genome, Plant \& Animal Genomes XIII Conference, San Diego (http://www.intlpag.org/13/abstracts/PAG13_W026.html).

Dalziel A.C., Stewart D.T., 2002. Tissue-specific expression of male-transmitted mitochondrial DNA and its implications for rates of molecular in Mytilus mussels (Bivalvia: Mytilidae). Genome 45, 348-355.

Diatchenko, L., Lukyanov, S., Lau, Y.F., Siebert, P.D., 1999. Suppression subtractive hybridization: a versatile method for identifying differentially expressed genes. Methods Enzymol. 303, 349-380.

Donald, K.M., Hawkins, A.J.S., Smerdon, G.R., 2001. Transcript analysis of the genes encoding aminopeptidase $\mathrm{N}$ and alanine aminotransferase, two enzymes involved in protein turnover, in the Pacific oyster, Crassostrea gigas. Comp. Biochem. Physiol. B 128, 459-467.

Dubos, M. P., Badariotti, F., Rodet, F., Lelong, C., Favrel, P., 2003. Molecular and physiological characterization of an invertebrate homologe of a calcitonin-related receptor. Biochem. Biophys. Res. Commun. 310, 972-978.

Duplessis, M.R., Dufour, S.C., Blankenship, L.E., Felbeck, H., Yayanos, A.A., 2004. Anatomical and experimental evidence for particulate feeding in Lucinoma aequizonata and Parvilucina tenuisculpta (Bivalvia: Lucinidae) from the Santa Barbara basin. Mar. Biol. 145, 551-561.

Elfstrom, C.M., Gaffney, P.M., Smith, C.T., Seeb, J.E., 2005. Characterization of 12 single nucleotide polymorphisms in weathervane scallop. Mol. Ecol. Notes, 5, 406-409. 
Evans, F., S. Matson, J. Brake \& C. Langdon.2003. The effects of inbreeding on performance traits of adult Pacific oysters (Crassostrea gigas). Aquaculture 230: 89-98

Fuentes, J.M., López, J.L., Mosquera, E., Vázquez, J., Villalba, A., Alvarez, G., 2002. Growth, mortality, pathological conditions and protein expression of Mytilus edulis and M. galloprovincialis crosses cultured in the Rías de Arousa (NW of Spain). Aquaculture 213: 233-251.

Funabara, D., Kinoshita, S., Watabe, S., Siegman, M.J., Butler, T.M., Hartshorne, D.J., 2001 a. Phosphorilation of molluscan twitchin by the camp-dependent protein kinase. Biochemistry 40, 2087-2095.

Funabara, D., Nakaya, M., Watabe, S., 2001 b. Isolation and characterization of a novel 45 $\mathrm{kDa}$ calponin-like protein from anterior byssus retractor muscle of the mussel Mytilus galloprovincialis. Fish. Sci. 67. 511-517.

Gaffney, P., Pierce, J.C., Mackinley, A., Titchen, D., Glenn, W.K., 2003. Pearl, a novel family of putative transposable elements in bivalve mollusks. J. Mol. Evol. 56, 308316.

Gibson, G., Muse, S.V., 2002. A primer of genome science. Sinauer, Sunderland.

Giribet, G., Carranza, S., 1999. What can 18S rDNA do for bivalve phylogeny? J. Mol. Evol. 48, 256-261.

Giribet, G., Wheeler, W., 2002. On bivalve phylogeny: a high-level analysis of the Bivalvia (Mollusca) based on combined morphology and DNA sequence data. Inv. Biol. 121, 271-324.

Goldberg, R.B., Crain W.R., Ruderman, J.V., Moore, G.P., Barnett, T.R., Higgins, R.C., Gelfland, R.A., Galau G.A., Britten R.J., Davidson, E.H., 1975. DNA sequence organization in the genomes of five marine invertebrates. Chromosoma (Berlin) 51, 225-251.

Goldstein, D.B., Schlötterer, C., 1999. Microsatellites: evolution and applications. Oxford University Press, Oxford, ?? pp.

González- Tizón, A., Martínez-Lage, A., Mariñas, L., Freire, R., Cornudella, L., Méndez, J., 1998. Cytogenetic characterization of Donax trunculus (Mollusca, Bivalvia). Cytogenet. Cell Genet. 81, 109.

Gosling, E., 2003. Bivalve molluscs: biology, ecology, culture. Fishing News Books, Oxford, ?? pp.

Gregory, T.R., 2005. Animal genome size database (http://www.genomesize.com).

Gregory, T.R. (2004). Macroevolution, hierarchy theory, and the C-value enigma. Paleobiology 30: 179-202.

Gueguen, Y., Cadoret, J.-P., Flament, D., Barreau-Roumiguière, C., Girardot, A.-L., Garnier, J., Horeau, A., Bachère, E., Escoubas, J.-M., 2003. Immune gene discovery by expressed sequence tags generated from hemocytes of the bacteria-challenged oyster, Crassostrea gigas. Gene 303, 139-145.

Guo, X., Allen Jr., S.K., 1997. Fluorescence in situ hybridization of the vertebrate telomere sequence to chromosome ends of the Pacific oyster, Crassostrea gigas Thunberg. J. Shellfish Res. 16, 87-89.

Hedgecock, D., Gaffney, P., Goulletquer, P., Guo, X., Reece, K., Warr, G.W., 2005. The case for sequencing the oyster genome. J. Shellfish Res. 24, 429-442

Hedgecock, D., G. Li, and M.-L. Voigt. 2004. Mapping heterosis QTL in the Pacific oyster Crassostrea gigas. http://www.intl-pag.org/12/abstracts/W06_PAG12_19.html. 
Hedgecock, D., Lin, J.-Z., De Cola, S., Haudenschild, C., Meyer, E., Nanahan, D.T., Bowen, B., 2002. Analysis of gene expression in hybrid Pacific oysters by massively parallel signature sequencing. Plant \& Animal Genome X Conf. Abstract (http://www.intl-pag.org/pag/10/abstracts/PAGX).

Hedgecock, D., McGoldrick, D.J., Manahan, D.T., Vavra, J., Appelmans, N., Bayne, B.L., 1996. Quantitative and molecular genetic analyses of heterosis in bivalve molluscs. J. Exp. Mar. Biol. Ecol. 203, 49-59.

Hubert, S., Hedgecock, D., 2004. Linkage maps of microsatellite DNA markers for the Pacific oyster Crassostrea gigas. Genetics 168, 351-362.

Huvet, A., Herpin, A., Degremont, L., Labreuche, Y., Samain, J.-F., Cunningham, C., 2004. The identification of genes from the oyster Crassostrea gigas that are differentially expressed in progeny exhibiting opposed susceptibility to summer mortality. Gene 343, 211-220.

Inoue, K., Takeuchi, Y., Miki, D., Odo, S., Harayama, S., Waite, J.H., 1996. Cloning, sequencing and sites of expression of genes for the hydroxyarginine-containing adhesive-plaque protein of the mussel Mytilus galloprovincialis. Eur. J. Biochem. 239, 172-176.

Ioannou, P.A., Amemiya, C.T., Garnes, J., Kroisel, P.M., Shizuya, H., Chen, C., Batzer, M. A., de Jong, P.J., 1994. A new bacteriophage P1-derived vector for the propagation of large human DNA fragments. Nat. Genet. 6, 84-89.

Iwasaki, K., Kikuchi, K., Funabara, D., Watabe, S., 1997. cDNA cloning of tropomyosin from the anterior byssus retractor muscle of mussel and its structural integrity from the deduced amino acid sequence. Fish. Sci. 63, 731-734.

Jenny, M.J., Ringwood, A.H., Lacy, E.R., Lewitus, A.J., Kempton , J.W., Gross, P.S., Warr, G.W., Chapman, R.W., 2002. Potential indicators of stress response identified by expressed sequence tag analysis of hemocytes and embryos from the American oyster, Crassostrea virginica. Mar. Biotechnol. 4, 81-93.

Jenny, M.J., Ringwood, A.H., Schey, K., Warr, G.W., Chapman, R.W., 2004. Diversity of metallothioneins in the American oyster Crassostrea virginica, revealed by transcriptomic and proteomic approaches. Eur. J. Biochem. 271, 1702-1712.

Jia, Y., Lu, Z., Huang, K., Herzberg, O., Dunaway-Mariano, D., 1999. Insight into the mechanism of phosphoenolpyruvate mutase catalysis derived from site-directed mutagenesis studies of active sie residues. Biochemistry 38, 14165-14173.

Kenchington, E., MacDonald, B., Cao, L., Tsagarakis, D., Zouros, E., 2002. Genetics of mother-dependent sex ratio in blue mussels (Mytilus spp.) and implications for doubly uniparental inheritance of mitochondrial DNA. Genetics 161, 1579-1588.

Kim, U.J., Shizuya, H., de Jong, P.J., Birren, B., Simon, M.I., 1992. Stable propagation of cosmid sized human DNA inserts in an F factor based vector. Nucleic Acids Res. 20, 1083-1085.

Kimura, T., Nakano, T., Yamaguchi, T., Sato, M., Ogawa, T., Muramoto, K., Yokoyama, T., Kan-no, N., Nagahisa, E., Janssen, F., Grieshaber, M.K., 2005. Complementary cDNA cloning and molecular evolution of opine dehydrogenases in some marine invertebrates. Mar. Biotechnol. 6, 493-502.

Knauer, J., Southgate, P.C., 1999. A review of the nutritional requirements of bivalves and the development of alternative and artificial diets for bivalve aquaculture. Rev. Fish. Sci. 7, 241-280. 
Knigge, T., Monsinjon, T., Andersen, O.K., 2004. Surface-enhanced laser desorption/ionization-time of flight-mass spectometry approach to biomarker discovery in blue mussels (Mytilus edulis) exposed to polyaromatic hydrocarbons and heavy metals under field conditions. Proteomics 4, 2722-2727.

Korringa, P., 1976. Farming the flat oysters of the genus Ostrea. Elsevier Scientific Publishing Company, New York, ?? pp.

Korringa, P., 1979. Farming the cupped oysters of the genus Crassostrea. Elsevier Scientific Publishing Co., New York ?? pp.

Kozhemyako, V.B., Rebrikov, D.V., Lukyanov, S.A., Bogdanova, E.A., Marin, A., Mazur, A.K., Kovalchuk, S.N., Agafonova, E.V., Sova, V.V., Elyakova, L.A., Rasskazov, V.A., 2004. Molecular cloning and characterization of an endo-1,3,- $\beta$-D-glucanase from the mollusk Spisula sachalinensis. Comp. Biochem. Physiol. B 137, 169-178.

Kwok, P.-Y., 2001. Methods for genotyping single nucleotide polymorphisms. Ann. Rev. Genomics Hum. Genet. 2, 235-258.

Ladoukakis, E.D., Zouros, E., 2001. Direct evidence for homologous recombination in mussel (Mytilus galloprovincialis) mitochondrial DNA. Mol. Biol. Evol. 18,: 11681175.

Langdon, C., Evans, F., Jacobson, D., Blouin, M., 2003. Yields of cultured Pacific oysters Crassostrea gigas Thunberg improved after one generation of selection. Aquaculture 220: 227-244.

Li, L., Guo, X., 2004. AFLP-based genetic linkage maps of the Pacific oyster Crassostrea gigas Thunberg. Mar. Biotechnol. 6: 26-36.

Li, S., Xie, L., Zhang, C., Zhang, Y., Gu, M., Zhang, R., 2004. Cloning and expression of a pivotal calcium metabolism regulator: calmodulin involved in shell formation from pearl oyster (Pinctada fucata). Comp. Biochem. Physiol. B 138, 235-243.

Liu, B.-H., 1997. Statistical Genomics: linkage, mapping and QTL analysis, CRC Pres, Boca Raton, ?? ppp.

Loosanoff, V.L., Davis, H.C., 1963. Rearing of bivalve mollusks. Adv. Mar. Biol.1, 1-136.

López, J. L., Abalde, S.L., Fuentes, J., 2005. Proteomic approach to probe for larval proteins of the mussel Mytilus galloprovincialis. Mar. Biotecnol. 7: 396-404.

López, J.L., Marina, A., Alvarez, G., Vázquez, J., 2002. Application of proteomics for fast identification of species-specific peptides from marine species. Proteomics 2, 16581665.

López, J.L., Marina, A., Vázquez, J., Alvarez, G., 2002. A proteomic approach to the study of the marine mussels Mytilus edulis and M. galloprovincialis. Mar. Biol. 141: 217-223.

López, J. L., Mosquera, E., Fuentes, J., Marina, A., Vázquez, J., Alvarez, G., 2001. Two dimensional gel electrophoresis of Mytilus galloprovincialis: differences in protein expression between intertidal and cultured mussels. Mar. Ecol. Prog. Ser. 224, 149-156.

López-Flores, I., de la Herrán, R., Garrido-Ramos, M.A., Boudry, P., Ruiz-Rejón, C., RuizRejón, M., 2004. The molecular phylogeny of oysters based on satellite DNA related to transposons. Gene 339, 181-188.

Martínez-Lage, A., Rodríguez-Fariña, F., González-Tizón, Méndez, J., 2005. Origin and evolution of Mytilus mussel satellite DNAs. Genome 8, 247-256.

Martínez-Lage, A., Rodríguez, F., González-Tizón, Prats, E., Cornudella, L., Méndez, J., 2002. Comparative analysis of different satellite DNAs in four Mytilus species. Genome 45: 922-929. 
Matsumoto, T., Nakamura, A. M., Mori, K., Kayano, T., 2003.Molecular characterization of a cDNA encoding putative vitellogenin from the Pacific oyster Crassostrea gigas. Zool. Sci. 20, 37-42.

McGoldrick, D.J., Hedgecock, D., 1997. Fixation, segregation and linkage of allozyme loci in inbred families of the Pacific oyster Crassostrea gigas (Thunberg): implications for the causes of inbreeding depression. Genetics 146, 321-334.

McGoldrick, D.J., Bayne, B.L., Innes, B., Ho Ha, J., Ward, R.D., 2002. Updating our progress in the mapping of major genes in the Pacific oyster (Crassostrea gigas), Aquaculture 204, 229-?.

McKillen, D.J., Chen, Y.A., Chen, C., Jenny, M.J., Trent, H.F., $3^{\text {rd }}$, Robalino, J., McLean, C.C., Jr, Gross, P.S., Chapman, R.W., Warr, G.W., Almeida, J.S., 2005. Marine Genomics: a clearing house for genomic and transcriptomic data of marine organisms. MBC Genomics 6, 34-?.

Milbury, C. A., Meritt, D. W., Newel, R. I. E., Gaffney, P. M., 2004. Mitochondrial DNA markers allow monitoring of oyster stock enhancement in the Cheaspeake Bay. Mar Biol. 145: 351-359.

Miller, C.M., Ming, T.J., Schulze, A.D., Withler, R.E., 1999. Denaturing gradient gel electrophoresis (DGGE): a rapid and sensitive technique to screen nucleotide sequence variation in populations. Biotechniques 27, 1016-1030.

Mitta, G., Vandenbulcke, F., Hubert, F., Salzet, M., Roch, P., 2000. Involvement of Mytilins in mussel antimicrobial defense. J. Biol. Chem. 17, 12954-12962.

Miyamoto, M., Hamaguchi, M., Okoshi, K., 2002. Analysis of genes expressed in the mantle of oyster Crassostrea gigas. Fish. Sci. 68, 651-658.

Mizi, A., Zouros, E., Moschonas, N., Rodakis, G.C., 2005. The complete maternal and paternal mitochondrial genomes of the mediterranean mussel Mytilus galloprovincialis: Implications for the Doubly Uniparental Inheritance Mode of mtDNA. Mol. Biol. Evol. 22, 952 - 967.

Montagnani, C., Le Roux, F., Berthe F. and Escoubas, J.-M., 2001. Cg-TIMP, an inducible tissue inhibitor of metalloproteinase from the Pacific oyster Crassostrea gigas with a potential role in wound healing and defence mechanisms. FEBS Letters 500, 64-70.

Moon van der Staay, S.Y., De Wachter, R, Vaulot D., 2001. Oceanic 18S rDNA sequences from picoplancton reveal unsuspected eukaryotic diversity. Nature 409, 607-610.

Nell, J.A., 2002. Farming triploid oysters. Aquaculture 126, 69-88.

Nell, J.A., Hand, R.E., 2003. Evaluation of the progeny of second-generation Sidney rock oyster Saccostrea glomerata (Gould, 1850) breeding lines for resistance to QX disease Marteilia sidneyi. Aquaculture 228, 27-35.

Nell, J.A., Smith, I.R., Sheridan, A.K., 1999. Third generation evaluation of Sidney rock oyster Saccostrea commercialis (Iredale and Roughley) breeding lines. Aquaculture 170,195-203.

Nijman, I.J., Lenstra, J.A., 2001. Mutation and recombination in cattle satellite DNA:a feedback model for the evolution of satellite DAN repeats. J. Mol. Evol. 52, 361-371.

Nilsen, I.W., Myrnes, B., 2001. The gene of chlamysin, a marine invertebrate-type lysozyme, is organized similar to vertebrate but different from invertebrate chickentype lysozyme genes. Gene 269, 27-32.

Ng, S.H., Artieri, C.G., Bosdet, I.E., Chiu, R., Dnazmann, R.G., Davidson, W.S., Ferguson, M.M., Fjell, C.D., Hoyheim, B., Jones, S.J., de Jong, P.J., Koop, B.F., Krzywinski, M.I., Lubieniecki, K., Marra, M.A., Mitchell, L.A., Mathewson, C., Osoegawa, K., 
Parisotoo, S.E., Phillips, R.B., Rise, M.L., von Schalburg, K.R., Schein, J.E., Shin, H., Siddiqui, A., Thorsen, J., Wye, N., Yang, G., Zhu, B., 2005. A physical map of the genome of Atlantic salmon, Salmo salar. Genomics 86, 396-404.

Orita, M., Iwahana, H., Kanzawa, H., Hayashi, K., Sekiya, T., 1989. Detection of polymorphisms of human DNA by gel electrophoresis as single-strand conformation polymorphisms. Proc. Natl. Acad. Sci. USA 86, 2766-2770.

Ortí, G., Hare, M.P., Avise, C., 1997. Detection and isolation of nuclear haplotypes by PCR-SSCP. Mol. Ecol. 6, 575-580.

Pérez-Parallé, M.L., Carpintero, P., Pazos, A.J., Abad, M., Sánchez, J.L. 2005. The HOX gene cluster in the bivalve mollusc Mytilus galloprovincialis. Biochem. Genet. 43, 417424.

Petrovic, V., Plohl, M., 2005. Sequence divergence and conservation in organizationally distinct subfamilies of Donax trunculus satellite DNA. Gene 362:37-43.

Piro, M.C., Gambacurta,A., Basili, P., Ascoli, F., 1998. Te exon/intron organization of the globin gene of Scapharca inaequivalvis homodimeric hemoglobin: unusual intron homology with other bivalve mollusc globin genes. Gene 221, 45-49.

Plohl, M., Cornudella, L., 1996. Characterization of a complex satellite DNA in the mollusk Donax trunculus: anlaysis of sequence variation and divergence. Gene 169, 157-164.

Plohl, V., Cornudella, L., 1997. Characterization of interrelated sequence motifs in four satellite DNAs and their distribution in the genome of the mollusk Donax trunculus. J. Mol. Evol. 44, 189-198.

Plohl, M., Prats, E., Martínez-Lage, A., González-Tizón, A., Méndez, J., Cornudella, L., 2002. Telomeric localization of the vertebrate-type hexamer repeat (TAGGG)n, in de wedgeshell clam Donax trunculus and other marine invertebrate genomes. J. Biol. Chem. 277, 19-839-19846.

Pogson, G.H., Zouros, E., 1994. Allozyme and RFLP heterozygosities as correlates of growth rate in the scallop Placopecten magellanicus: a test of associative overdominance hypothesis. Genetics 137, 221-231.

Poustka, A.J., Groth, D., Hennig, S., Thamm, S., Cameron, A., Beck, A., Reinhardt, R., Herwig, R., Panopoulou, G., Lehrach, H., 2003. Generation, annotation, evolutionary analysis, and database integration of 20,000 unique sea urchin EST clusters. Genome Res. 13, 2736-2746.

Reid, R.G., 1968. The distribution of digestive tract enzymes in lamellibranchiate bivalves. Com. Biochem. Physiol. 24, 727-744.

Rinkevich, B., 2005. Marine invertebrate cell cultures: new millenium trends. Mar. Biotechnol. 7, 429-439.

Rise, M.L., Schalburg, K.R., Brown, G.D., Mawer, M.A., Devlin, R.H., Kuipers, N., Busby, M., Beetx-Sargent, M., Alberto, R., Gibbs, A.R., Hunt, P., Shukin, R., Zeznik, J.A., Nelson, C., Jones, S.R., Smailus, D.E., Jones, S.J., Schein, J.E., Marra, M.A., Butterfield, Y.S., Scott, J.M., Ng, S.H., Davidson, W.S., Koop, B.F., 2004. Development and application of a salmonid EST database and sDNA microarray: data mining and interspecific hybridization characteristics. Genome Res. 14, 478-490.

Rodríguez-Ortega M, Grøsvik BE, Rodríguez-Ariza A, Goskøyr A, López-Barea J., 2003. Changes in protein expresion profiles in bivalve molluscs (Chamaellea gallina) exposed to four model environmental pollutants. Proteomics 3: 1535-1543. 
Rokas, A., Ladoukakis, E., Zouros, E., 2003. Animal mitochondrial DNA recombination revisited. Trens. Ecol. Evol. 18, 411-417.

Rossini, G.P., 2005. Functional assays in marine biotoxin detection. Toxicology 207, 451462.

Ruiz-Lara, S., Prats, E., Casas, M.T., Cornudella, L., 1993. Molecular cloning and sequence of a cDNA for sperm-specific protein Phi-1 from the mussel Mytilus edulis. Nuc. Acids Res. 21, 2774-?.

Ruiz-Lara, S., Prats, E., J. Sainz, Cornudella, L., 1992. Cloning and characterization of a highly conserved satellite DNA from the mollusc Mytilus edulis. Gene 117, 237-242

Saavedra, C., Reyero, M.-I., Zouros, E., 1997. Male dependent doubly uniparental inheritance of mitochondrial DNA and female dependent sex-ratio in the mussel Mytilus galloprovincialis. Genetics 145, 1073-1082.

Sarashina, I., Endo, K., 2001. The complete primary structure of molluscan shell protein 1 (MSP-1), and acidic glycoprotein in the shell matrix of the scallop Patinopecten yessoensis. Mar. Biotechnol. 3, 362-369.

Schena, M., Shalon, D., Davis, R.W., Brown, P.O., 1995. Quantitative monitoring of gene expression patterns with a cDNA microarray. Science 270, 467-470.

Schwarz-Sommer, Z., de Andrade Silva, E., Berndtgen. R., Lönnig, W.-E, Müller, A., Nindl, I., Stüber, K., Wunder J., Saedler, H., Gübitz, T., Borking, A., Golz, J. F., Ritter, E., Hudson, A., 2003. A linkage map of an $\mathrm{F}_{2}$ hybrid population of Antirrhinum majus and A. molle. Genetics 163, 699-710.

Sellos, D., Moal, J., Degremont, L., Huvet, A., Daniel, J.-Y., Nicoulaud, S., Boudry, P., Samain, J.-F., van Wormhoudt, A., 2003. Structure of amylase genes in populations of Pacific cupped oyster (Crassostrea gigas): tissue expression and allelic polymorphism. Mar. Biotechnol. 5, 360-372.

Sheridan, A.K., 1997. Genetic improvement of oyster production - a critique. Aquaculture 153, 165-179.

Shizuya, H., Birren, B., Kim, U. J., Mancino, V., Slepak, T., Tachiiri, Y., Simon, M., 1992. Cloning and stable maintenance of 300-kilobase-pair fragments of human DNA in Escherischia coli using an F-factor-based vector. Proc. Natl. Acad. Sci.USA 89, 87948797.

Shumway, S.E., Cembella, A.D., 1993. The impact of toxic algae on scallop culture and fiheries. Rev. Fish. Sci. 1, 121-150.

Skibinski, D.O.F., Gallagher, C., Beynon, C.M., 1994. Sex-limited mitochondrial DNA transmission in the marine mussel Mytilus edulis. Genetics 138, 801-809.

Steele, S., Throndyke, M., Wilkes, D. C., Goldspink, G., 1999. Isolation of RNA from Pacific oyster larvae using the SV total RNA isolation system. Promega Notes 71: 2-?.

Steiner, G., Müller, M., 1996. What can 18S rDNA do for bivalve Phylogeny? J. Mol. Evol. 43, 58-70.

Stoughton, R.B., 2005. Applications of DNA microarrays in Biology. Ann. Rev. Biochem. 74, 53-82

Suzuki, T., Sugimura, N., Taniguchi, T., Unemi, Y., Murata, T., Hayashida, M., Yokouchi, K., Uda, K., Furukohri, T., 2002. Two-domain arginine kinases from the clams Solen strictus and Corbicula japonica: exceptional amino acid replacemente of the functionally important D62 by G. Int. J. Biochem. Cell. Biol. 34, 1221-1229. 
Suzuki, T., Yamamoto, Y., 2000. Gene structure of two-domain arginine kinases from Anthopleura japonicus and Pseudocardium sachalinensis. Comp. Biochem. Physiol. B 127, 513-518.

Tagaki, M., Kikko, T., Hosoi, M., Hatashi, I., Toyohara, H., 2004. cDNA cloning of oyster matrix metalloproteinase and its possible involvement in hypoxic adaptation. Fish. Sci. 70, 682-687.

Takeuchi, M., Mizuta, C., Uda, K., Fujimoto, N., Okamoto, M., Suzuki, T., 2004. Unique evolution of Bivalvia arginine kinases. Cell Mol. Life Sci. 61, 110-117.

Tanguy, A., Boutet, I., Laroche, J., Moraga, D., 2005. Molecular identification and expression study of differentially regulated genes in the Pacific oyster Crassostrea gigas in response to pesticide exposure. FEBS J. 272, 390-403.

Tanguy, A., Boutet, I., Riso, R., Boudry, P., Auffret, Moraga, D., 2003. Metallothionein genes in the European flat oyster Ostrea edulis: a potential ecological tool forenvironmental monitoring. Mar. Ecol. Progr. Ser. 257, 87-97.

Tanguy, A., Guo, X., Ford, S. E., 2004. Discovery of genes expressed in response to Perkinsus marinus challenge in Eastern (Crassostrea virginica) and Pacific (C. gigas) oysters. Gene 338, 121-131.

Thiriot-Quiévreux, C., 1994. Advances in cytogenetics of aquatic organisms. In: Beaumont A.R. (Ed.), Genetics and evolution of aquatic organisms, pp. 36-388. Chapman and Hall, London.

Thorsen, J., Zhu, B., Freguen, E., Osoegawa, K., de Jong, P.J., Koop, B.F., Davidson, W.S., Hoyheim, B., 2005. A highly redundant BAC library of Atlantic salmon (Salmo salar): an important tool for salmon projects. BMC Genomics 6, 50

Venier, P., Pallavicini, A., De Nardi, B., Lanfranchi, G., 2003. Towards a catalogue of genes transcribed in multiple tissues of Mytilus galloprovincialis. Gene 314, 29-40.

Venter, J. C., Remington, K., Heidelberg, J. F., Halpern, A. L., Rusch, D., Eisen, J. A., Dongying Wu, Paulsen, I., Nelson, K. E., Nelson, W., Fouts, D. E., Levy, S., Knap, A. H., Lomas, M. W., Nealson, K., White, O., Peterson, J., Hoffman, J., Parsons, R., Baden-Tillson, H., Pfannkoch, C., Rogers, Y.-H., Smith, H. O., 2004. Environmental genome shotgun sequencing of the Sargasso Sea. Science 304: 66-74

Villalba, A., Reece, K.S., Ordás, M.C., Casas, S.M., Figueras, A., 2004. Perkinsosis in molluscs: a review. Aquat. Living Resour. 17, 411-432.

Von Schalburg, K.R, Rise, M.L., Cooper, G.A., Brown, G.D., Gibbs, A.R., Nelson, C.C., Davidson, W.S., Koop, B.F., 2005. Fish and chips: various methodologies demonstrate the utility of a 16,006-gene salmonid microarray. MBC Genomics 6, 126-?.

Waite, J.H., Quin, X., 2001. Polyphosphoprotein from the adhesive pads of Mytilus edulis. Biochemistry 40, 2887-2893.

Walne, P.R., 1974. Culture of bivalve molluscs: 50 years’ experience at Conway. Fishing News Books, Oxford, ?? pp.

Wang, Y., Guo, X., 2001. Chromosomal mapping of the vertebrate telomeric sequence (TTAGGG)n in four bivalve molluscs by fluorescence in situ hybridization. J. Shellfish Res. 20, 1187-1190.

Wang, L., Song, L., Chang, Y., Xu, W., Ni, D., Guo, X., 2005. A preliminary genetic map of Zhikong scallop (Chlamys farreri Jones et Preston 1904). Aquaculture Res. 36, 643653. 
Wang, Y., Zu, Z., Guo, X., 2001. A centromeric satellite in the Pacific oyster (Crassostrea gigas Thunberg) identified by fluorescence in situ hybridization. Mar. Biotechnol. 3, 486-492.

Wang, Y., Xu, Z., Pierce, J.C., Guo, X., 2005. Characterization of Eastern oyster (Crassostrea virginica Gmelin) chromosomes by fluoresecence in situ hybridization with bacteriophage P1 clones. Mar. Biotechnol. 7, 207-214.

Watabe, S., Iwasaki, K., Funabara, D., Hirayama, Y., Nakaya, M., Kikuchi, K., 2000. Complete amino acid sequence of Mytilus anterior byssus retractor paramyosin and its putative phosphorylation site. J. Exp. Zool.286: 24-35.

Xu, B., Janson, J.C., Sellos, D., 2001. Cloning and sequencing of a molluscan endo- $\beta-1,4-$ glucanase gene from the blue mussel, Mytilus edulis. Eur. J. Biochem 268, 3718-3727.

Xu, B., Sellos, D., Janson, J.C., 2002. Cloning and expression in Pichia pastoris of a blue mussel (Mytilus edulis) $\beta$-mannanase gene. Eur. J. Biochem 269, 1753-1760.

Yamada, A., Yoshio, M., Iowa, K., Nyitray, L., 1999. Catchin, a novel protein in molluscan catch muscles, is produced by alternative splicing from the myosin heavy chain gene. J. Mol. Biol. 295, 169-178.

Yang, H.-L., Zeng, Q.-Y., Li, E.-Q., Zhu, S.-G., Zhou, X.-W., 2004.Molecular cloning, expression and characterization of glutathione S-transferase from Mytilus edulis. Comp. Biochem. Physiol. B 139, 175-182.

Yu, Z., Guo, X., 2003. Genetic linkage map of the eastern oyster Crassostrea virginica Gmelin. Biol. Bull. 204, 327-338.

Zhang, Y., Meng, Q., Jiang, T., Wang, H., Xie, L., Zhang, R., 2003. A novel ferritin subunit involved in shell formation from the pearl oyster (Pinctada fucata). Comp. Biochem. Physiol. B 135, 43-54.

Zheng, H.P., Zhang, G.F., Liu X., Zhang, F.S., Guo, X., 2004. Different responses to selection in two sptocks of the bay scallop, Argopecten irradians irradians Lamarck (1819). J. Exp. Mar. Biol. Ecol. 313,: 213-223.

Zouros, E., 2001. The exceptional mitochondrial DNA system of the mussel family Mytilidae. Genes Genet. Syst. 75, 313-318.

Zouros, E., Ball, A.O., Saavedra, C., Freeman, K.R. 1994. A new type of mitochondrial DNA inheritance in the blue mussel Mytilus. Proc. Natl. Acad. Sci. USA 91,: 7463-74 
Table 1. EST collections from bivalves that have been submitted to public databases. DP, Dreissena polymorpha. Other species abbreviations as in Fig. 2.

No. of

Species Author (lab)

Tissue

ESTs

Oyster $\quad$ J.M. Escoubas, E. Bachere (CRS- $\quad$ Hemocytes 1142

CG IFREMER, France)

X. Guo (Haskin Shellfish Research Hemocytes, gill

70

Laboratory, USA)

A. Huvet (IFREMER, France)

Mantle / gonad

137

substracted library

A.H. Kausland (SARS Centre, Mantle

Norway)

D. Moraga (Université Bretagne

Gonad, digestive gland

377

Occidentale, France)

G.P. Rafferty (National University of

Gill

106

Ireland) 
Table 1 (continued)

No. of

Species Author (lab)

Tissue

ESTs

Oyster P.S. Gross (Medical University of Hepatopancreas, hemocytes 4145

CV South Carolina, USA)

M.J. Jenny (Medical University of Veliger larvae 418

South Carolina, USA)

Z.J. Liu (Auburn University, $\quad$ Gill, Gonad 4348

USA)

X. Guo (Haskin Shellfish $\quad$ Substracted library form $\quad 177$

Research Laboratory, USA) hemocytes, and gill

Mussel P. Venier (University of Padova, Whole body 3986

MG Italy)

Scallop S. B. Roberts (Woods Hole MBL， Spat, gonad, adductor muscle, 2089

AI

USA) larvae

L. Wu (Chinese Academy of $\quad$ Whole body 4968

Sciences) 
Table 1 (continued)

\begin{tabular}{lllc}
\hline Species & Author (lab) & Tissue & ESTs \\
& & & \\
Scallop PM & I. A. Johnston (Gatty marine & Adductor & 1129 \\
& Laboratory, UK) & muscle & \\
Freshwater mussel & J. M. Danger (University of Le & - & 241 \\
DP & Havre, France) & &
\end{tabular}


Fig. 1. “Top 12” species in global aquaculture. Data from FAO

(http://apps.fao.org/default.jsp) for year 2002. Hatched bars highlight the 3 bivalves included.

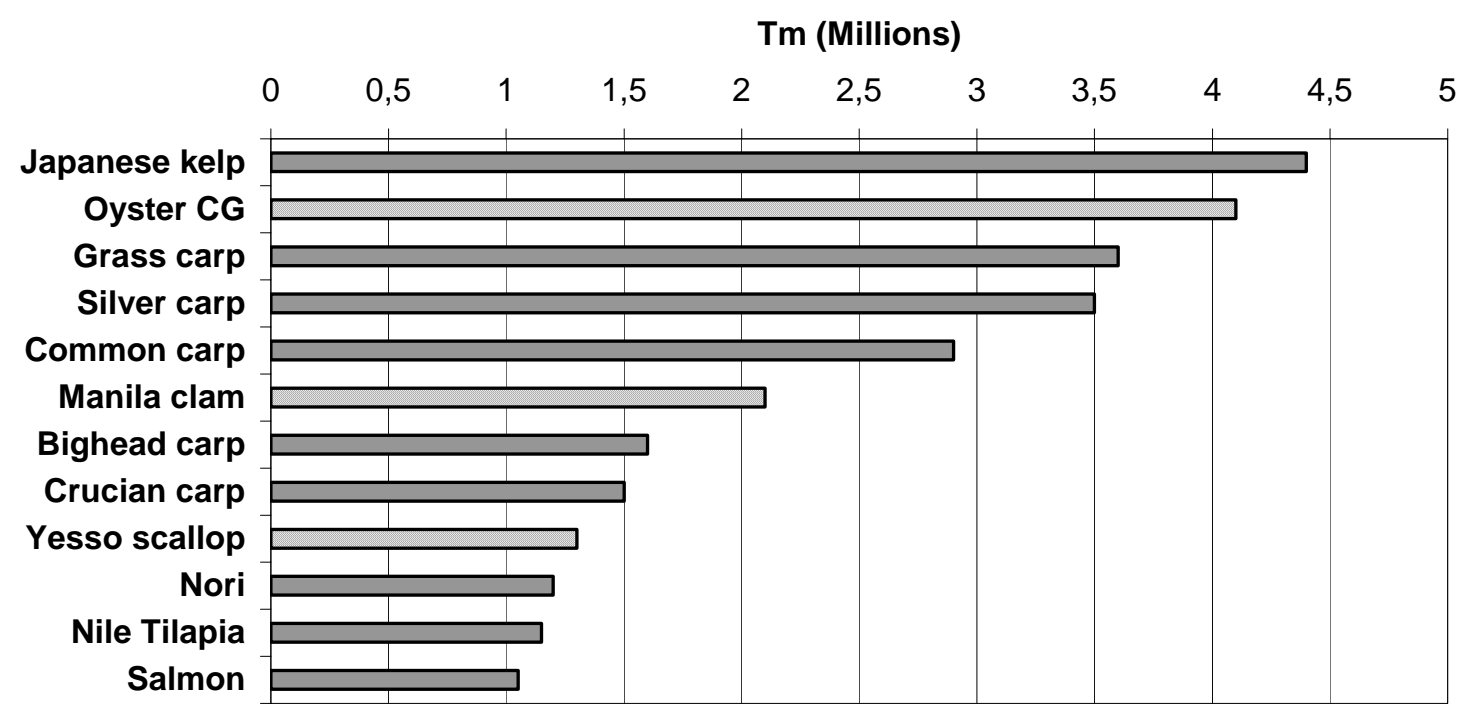


Fig. 2. Genome size of selected aquacultured bivalves (black) as compared to other marine organisms (hatched) and sequenced genomes (white). Data on non-sequenced organisms were obtained from the genome size database (www.genomebase.org). Abreviations: AI, Argopecten irradians; CG, Crassostrea gigas; CV, C. virginica; ME, Mytilus edulis; MG, M. galloprovincialis; PM, Pecten maximus; TP, Ruditapes philippinarum

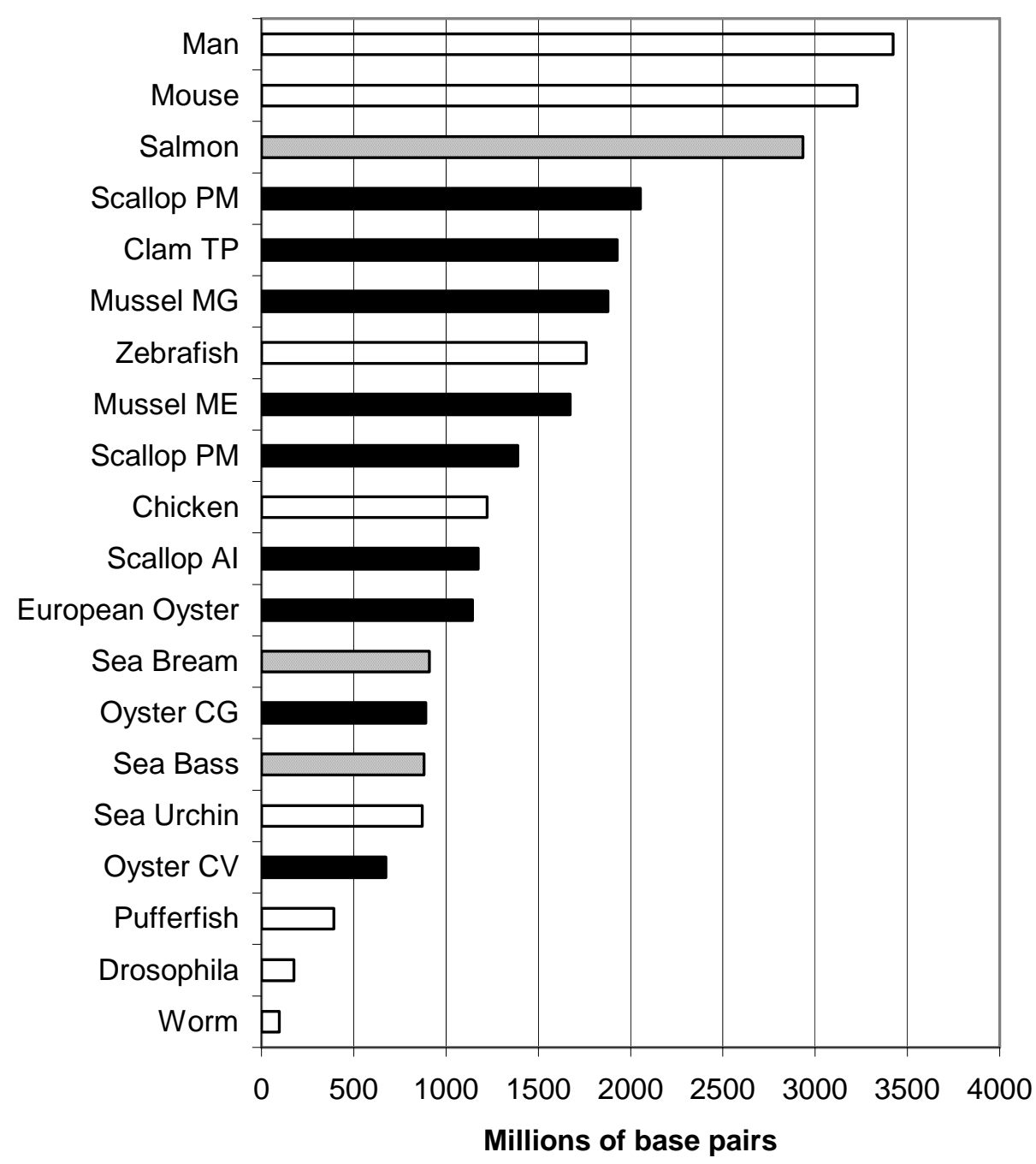


Fig. 3. Bivalves in public databases. A: Abundance of different types of bivalve DNA sequences in GenBank. B: Distribution of bivalve nuclear DNA sequences (excluding microsatellites) in GenBank by species or genera. Percents are indicated when they are above $1 \%$.
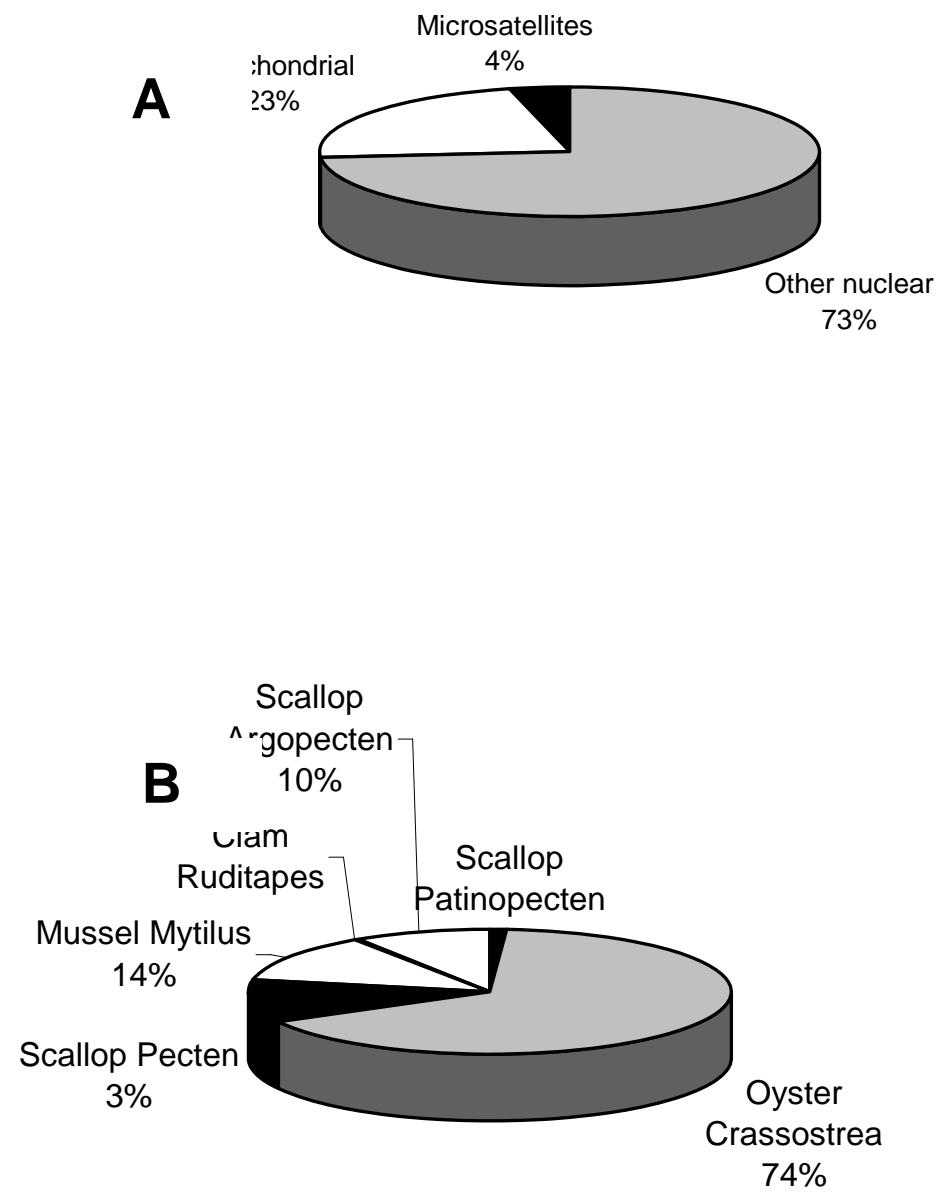
Fig. 4. Total number of ESTs obtained (bars) and relative frequency of sequences which could not be assigned to groups of known proteins (dots and line) in 4 cDNA libraries of bivalves which have been described in detail in the literature (Miyamoto et al., 2002; Jenny et al., 2002; Venier et al., 2003). Species abbreviations as in Fig. 2.

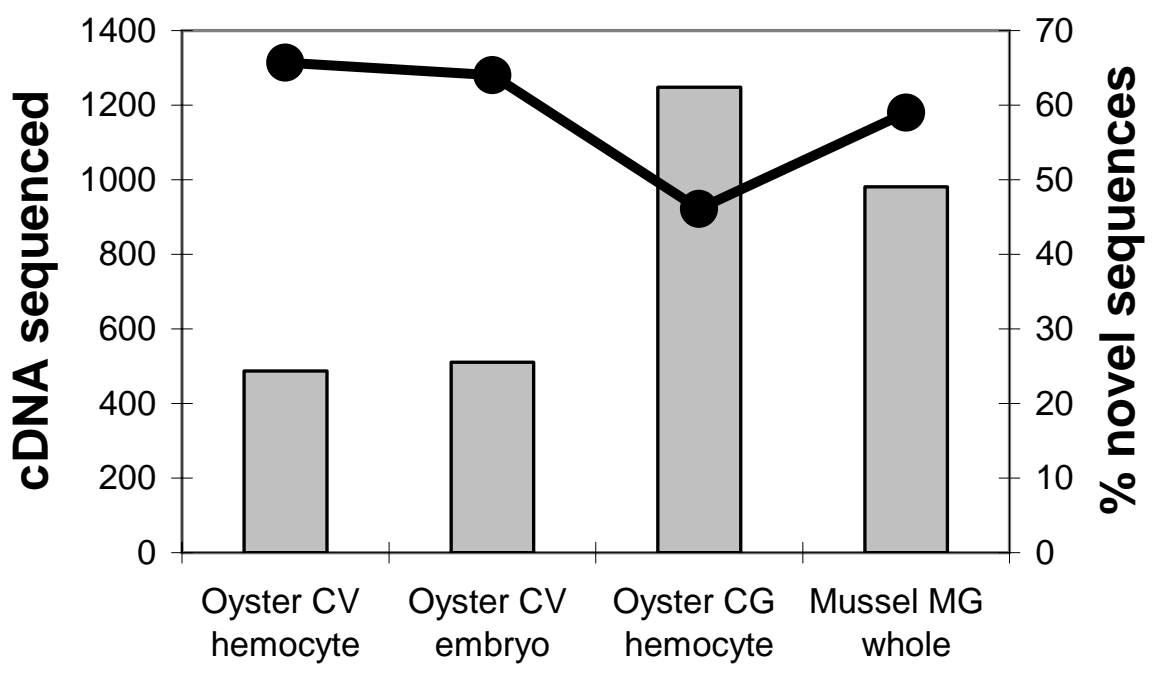

